\title{
PENGARUH METODE MENGAJAR GURU DAN KEMANDIRIAN BELAJAR TERHADAP PRESTASI BELAJAR SISWA MADRASAH ALIYAH KAB. KUDUS
}

\author{
Rofiq Faudy Akbar \\ Dosen Sekolah Tinggi Agama Islam Negeri Kudus \\ rofiqfa@gmail.com
}

\begin{abstract}
Student achievement can be regarded as indicators of the success of a learning process, which is a measure of success for teachers to conduct the necessary improvements. This study aimstodetermine the effect ofteaching methodthatis appliedandindependent learningon student achievement. The research method is quantitative by using multiple regression analysis. The respondents are students of class XII Madrasah Aliyah in Kudus, the number of sample is 187 students from 17 schools. The results of the study revealed that teachers' teaching method and student learning independence affect learning achievement of 56.9\%. Teacher's teaching style and student learning independence significant positive effect on learning achievement with a significance level less than $1 \%$.
\end{abstract}

Keywords: Method, Student Learning Independence, Achievement

\begin{abstract}
Abstrak
Prestasi belajar siswa dapat dikatakan sebagai indikator keberhasilan suatu proses pembelajaran, dimana keberhasilan tersebut menjadi tolok ukur bagi pengajar untuk mengadakan perbaikan-perbaikan yang diperlukan. Penelitian ini bertujuan untuk mengetahui pengarub metode mengajar yang diterapkan dan kemandirian belajar terbadap prestasi belajar siswa. Metode penelitian adalab kuantitatif dengan menggunakan analisis regresi berganda.Responden penelitian merupakan siswa kelas XII Madrasab Aliyahdi Kabupaten Kudus dengan jumlah Sampel sebanyak 187 siswa dari 17 sekolah. Hasil penelitian mengungkap babwa metode mengajar guru dan kemandirian belajar siswa mempengarubi prestasi belajar sebesar 56,9\%. Metode mengajar guru dan kemandirian belajar siswa secara signifikan berpengaruh positif terhadap prestasi belajar dengan tingkat signifikansi kurang dari 1\%.
\end{abstract}

Kata kunci : Metode, Kemandirian,Prestasi Belajar 


\section{Pendahulauan}

Belajar dapat dikatakan sebagai sebuah proses, yaitu serangkaian aktivitas yang terjadi pada pusat saraf individu untuk menangkap berbagai informasi dari luar. Proses belajar terjadi secaraabstrak, karena terjadi secara mental dan tidak dapat diamati. Proses belajar hanya dapat diamati jika ada perubahan perilaku dari seseorang yang berbeda dengan sebelumnya. Perubahan perilaku tersebut bisa dalam hal pengetahuan, afektif, maupun psikomotoriknya. Menurut Gagne (dalam Burhanuddin \& Wahyuni, 2010 : 17-18), proses belajar terjadi melalui tahap-tahap atau fase-fase seperti: motivasi, konsentrasi, mengolah, menggali 1, menggali 2, prestasi, dan umpan balik.

Pada tahap yang pertama, tahap motivasi yaitu saat motivasi dan keinginan siswa untuk melakukan kegiatan belajar bangkit. Dalam tahap ini seorang guru harus pandai-pandai memotivasi siswa sehingga motivasi mereka dalam mengikuti pembelajaran meningkat. Setelah motivasi siswa meningkat diharapkan mereka akan masuk pada tahap kedua yaitu tahap konsentrasi, dimana siswa harus memusatkan perhatian, yang telah ada pada tahap motivasi, untuk tertuju pada hal-hal yang relevan dengan apa yang akan dipelajari.

Tahap yang ketiga adalah tahap mengolah, pada tahap ini siswa menahan informasi yang diterima dari guru dalam Short Term Memory, atau tempat penyimpanan ingatan jangka pendek, kemudian mengolah informasi-informasi untuk diberi makna (meaning) berupa sandi-sandi sesuai dengan penangkapan masing-masing.

Selanjutnya adalah tahap menyimpan, yaitu siswa menyimpan simbol-simbol hasil olahan yang telah diberi makna ke dalam Long Term Memory (LTM) atau gudang ingatan jangka panjang. Pada tahap ini hasil belajar sudah diperoleh, baik baru sebagaian maupun keseluruhan. Perubahan-perubahan pun sudah terjadi, baik perubahan pengetahuan, sikap, maupun keterampilan.

Proses berikutnya adalah tahap menggali (1), yaitu siswa menggali informasi yang telah disimpan dalam LTM ke STM untuk dikaitkan dengan informasi baru yang dia terima. Ini terjadi pada pelajaran waktu berikutnya yang merupakan kelanjutan pelajaran 
sebelumnya. Setelah penggalian informasi dan dikaitkan dengan informasi baru, maka terjadi lagi pengolahan informasi untuk diberi makna seperti halnya dalam tahap mengolah untuk selanjutnya disimpan dalam LTM lagi. Tahap menggali (2), peserta didik menggali informasi yang telah disimpan dalam LTM untuk persiapan fase prestasi, baik langsung maupun melalui STM (Short Term Memory). Tahap menggali 2 diperlukan untuk kepentingan kerja, menyelesaikan tugas, menjawab pertanyaan atau soal/latihan.

Tahap Prestasi merupakan tahap menggunakan informasi yang telah tergali pada tahap sebelumnya untuk menunjukkan prestasi yang merupakan hasil belajar. Sebagai contoh hasil belajar antara lain berupa keterampilan mengerjakan sesuatu, kemampuan menjawab soal, atau menyelesaikan tugas. Tahap terakhir merupakan tahap Umpan Balik, dalam tahap ini siswa memperoleh penguatan (konfirmasi) atas prestasi yang ditunjukkan. Hal ini terjadi jika prestasinya tepat. Tapi sebaliknya, jika prestasinya jelek, perasaan tidak puas maupun tidak senang itu bisa saja diperoleh dari guru (eksternal) atau dari diri sendiri (internal).

Tahap-tahap pembelajaran sebagaimana yang diutarakan oleh Gagne diatas, memberikan penjelasan bahwa keberhasilan atau prestasi siswa dalam proses pembelajaran dipengaruhi oleh faktor internal dan eksternal. Faktor internal, berasal dari diri peserta didik sendiri sedangkan faktor eksternal berasal dari luar peserta didik seperti faktor guru dalam menyampaikan, metode yang digunakan, dan lingkungan yang mendukung. Begitu halnya yang dijelaskan oleh Ngalim Purwanto (2007: 107), bahwa prestasi belajar dapat dipengaruhi oleh faktor dari luar dan faktor dari dalam. Faktor dari luar berupa a). lingkungan, yang terdiri dari lingkungan alam dan lingkungan sosial, b) Instrumental, yang terdiri dari kurikulum / bahan ajar, guru/pengajar, sarana dan fasilitas dan administrasi / manajemen. Sedangkan faktor dari dalam a) Fisiologi, yang terdiri dari kondisi fisik dan kondisi panca indera. b) Psikologi, yang terdiri dari bakat, kecerdasan, motivasi, dan kemampuan kognitif.

Penelitian ini bertujuan untuk mengetahuipengaruhmetode mengajar yang diterapkan guru Madrasah Aliyah di Kabupaten Kudus secara umum dan kemandirian belajarterhadap prestasi belajar siswa. 


\section{Metode Mengajar}

Metode mengajar menurut Tardif (1989) dalam Muhibbin Syah (2008: 202) adalah cara yang berisi prosedur baku untuk melaksanakan kegiatan kependidikan, khususnya kegiatan penyajian materi pelajaran kepada siswa. Berdasarkan uraiantersebut dapat disimpulkan bahwa metode mengajar guru adalah suatu cara yang digunakan oleh guru dalam melaksanakan kegiatan pembelajaran di kelas agar tercipta suatu kondisi belajar yang efektif, khususnya dalam penyampaian materi pembelajaran.

Lebih lanjut Sudjana menjelaskan bahwa metode mengajar adalah cara yang dipergunakan guru dalammengadakan hubungan dengan siswa pada saat berlangsungnya pengajaran. Metode mengajar dapat dikatakan sebagai alat untuk menciptakan proses mengajar dan belajar(Sudjana, 2005: 76). Adapun jenis-jenis metode mengajar, menurut Sudjana antara lain :

a. Metode ceramah

Ceramah adalah penuturan bahan pelajaran secara lisan.

b. Metode tanya Jawab

Metode Tanya jawab adalah metode mengajar yang memungkinkan terjadinya komunikasi langsung yang bersifat two waytraffic sebab pada saat yang sama terjadi dialog antara guru dan siswa. Guru bertanya siswa menjawab, atau siswa bertanya guru menjawab.

c. Metode diskusi

Diskusi pada dasarnya ialah tukar menukar informasi, pendapat, dan unsur-unsur pengalaman secara teratur dengan maksud untuk mendapat pengertian bersama yang lebih jelas dan lebih teliti tentang sesuatu, atau untuk mempersiapkan dan merampungkan keputusan bersama.

d. Metode Tugas

Tugas dan resitasi tidak sama dengan pekerjaan rumah, tetapi jauh lebih luas dari itu.Tugas bisa dilaksanakan di rumah, di sekolah, di perpustakaan, dan di tempatlainnya. Tugas dan resitasi merangsang anak untuk aktif belajar baik secara individual maupun secara kelompok. 
e. Metode Demonstrasi dan Metode Eksperimen

Demonstrasi dan eksperimen merupakan metode mengajar yang sangat efektif, sebab membantu para siswa untuk mencari jawaban dengan usahasendiri berdasarkan fakta (data) yang benar. Demonstrasi yang dimaksud ialah suatu metode mengajar yang memperlihatkan bagaimana proses terjadinya sesuatu. Dalam pelaksanaannya demonstrasi dan eksperimen dapat digabungkan, artinya demonstrasi dulu lalu diikuti dengan eksperimen.

f. Metode Sosiodrama

Sosiodrama pada dasarnya mendramatisasikan tingkah laku dalam hubungannya dengan masalah sosial.Tujuan yang diharapkan dengan sosiodrama antara lain ialah :

- Agar siswa dapat menghayati dan menghargai perasaan orang lain.

- Dapat belajar bagaimana membagi tanggung jawab.

- Dapat belajar bagaimana mengambil keputusan dalam situasikelompok secara spontan.

- Merangsang kelas untuk berpikir dan memecahkan masalah.

g. Metode Karyawisata

Karyawisata dalam arti metode mengajar mempunyai arti tersendiri yang berbeda dengan karyawisata dalam arti umum. Karyawisata di sini berarti kunjungan ke luar kelas dalam rangka belajar.

\section{Kemandirian Belajar}

Dalam pembelajaran aktif, kemandirian merupakan unsur yang sangat penting karena kemandirian merupakan wujud dari keaktifan siswa. Pembelajaran akan dapat tercapai secara maksimal jika kemandirian ada pada masing-masing siswa. Umar Tirtarahardja dan S.L.La Sulo (2005: 50) menyatakan bahwa Kemandirian dalam belajar adalah aktivitas belajar yang berlangsungnya lebih didorong oleh kemauan sendiri, pilihan sendiri dan tanggung jawab sendiri.

Masing-masing siswa memiliki kecepatan dan kemandirian yang berbeda dalam memahami dan mendalami materi pembelajar- 
an. Kemandirian belajar siswa bervariasi dan berbeda-beda antara siswa satu dengan yang lainnya. Hamzah B.Uno(2007:51) mengemukakan bahwa ,metode belajar yang sesuai kecepatan sendiri juga disebut belajar mandiri. Maksud dari kecepatan sendiri adalah siswa memiliki tanggung jawab sendiri, sesuai dengan kecepatan sendiri untuk menciptakan belajar yang berhasil. Semuanya berdasarkan pada sasaran belajar khusus dan bermacam-macam kegiatan dengan beraneka sumber belajar yang berkaitan. Hal ini sesuai dengan apa yang dikemukakan AlidanAsrori (2005:117), bahwa ciri-ciri kemandirian terbagi menjadi beberapa tingkatan yaitu:

a. Tingkat sadar diri

Ini dapat ditafsirkan bahwa remaja telah memiliki kemampuan sebagai berikut.

1) Cenderung mampu berpikir alternatif.

2) Melihat berbagai kemungkinan dan situasi.

3) Peduli akan pengambilan manfaat dari situasi yang ada.

4) Berorientasi pada pemecahan masalah.

5) Memikirkan cara mengarungi hidup.

6) Berupaya menyesuasikan diri terhadap situasi dan peranan.

b. Tingkat seksama

1) Cenderung bertindak atas dasar nilai internal.

2) Melihat dirinya sebagai pembuat pilihan dan pelaku tindakan.

3) Melihat keragaman emosi, motif, dan prespektif diri sendiri maupun orang lain.

4) Sadar akan tanggung jawab.

5) Mampu melakukan kritik dan penilaian diri.

6) Peduli akan hubungan mutualistik.

7) Berorientasi pada tujuan jangka panjang.

c. Tingkat Individualistis

1) Memiliki kesadaran yang lebih tinggi akan individualitas.

2) Kesadaran akan konflik emosionalitas antara kemandirian dan ketergantungan. 
3) Menjadi lebih toleran terhadap diri sendiri dan orang lain.

4) Sadar akan eksistensi perbedaan individual.

5) Bersikap toleran terhadap perkembangan dalam kehidupan.

6) Mampu membedakan kehidupan dalam dirinya dengan kehidupan luar dirinya.

d. Tingkat Mandiri

1) Telah memiliki pandangan hidup sebagai suatu keseluruhan.

2) Bersikap objektif dan realistis terhadap diri sendiri maupun orang lain.

3) Mampu mengintegrasikan nilai-nilai yang bertentangan.

4) Ada keberanian untuk menyelesaikan konflik dalam diri.

5) Menghargai kemandirian orang lain.

6) Sadar akan adanya saling ketergantungan dengan orang lain.

7) Mampu mengekspresikan perasaannya dengan penuh keyakinan dan keceriaan.

Kemandirian belajar siswa, juga dipengaruhi oleh faktor internal yang berupa motivasi dari dalam diri siswa tersebut dan faktor eksternal yang berupa suntikan motivasi atau kebiasaan lingkungan. Faktor-faktor yang mempengaruhi kemandirian belajar menurut Alidan Asrori (2005:118), antara lain :

a. Gen atau keturunan orang tua. Orang tua yang memiliki sifat kemandirian tinggi seringkali menurunkan anak yang memiliki kemandirian juga.

b. Pola asuh orang tua. Cara orang tua mengasuh anak akan mempengaruhi perkembangan kemandirian anak.

c. Sistem pendidikan di sekolah. Proses pendidikan di sekolah yang tidak mengembangkan demokrasi pendidikan dan cenderung menekankan indoktrinisasi tanpa argumentasi akan menghambat perkembangan kemandirian. Sebaliknya, proses pendidikan yang lebih menekankan pentingnya penghargaan terhadap potensi anak, pemberian reward, danpenciptaan kompetitif positif akan memperlancar kemandirian.

d. Sistem pendidikan di masyarakat. Sistem kehidupan masyarakat yang terlalu menekankan pentingnya hierarki struktur sosial, 
merasa kurang aman atau tercekam serta kurang menghargai manifestasi potensi dalam kegiatan produktif, dapat menghambat kelancaran perkembangan kemandirian. Sebaliknya, lingkungan masyarakat yang aman, menghargai ekspresi potensi anak dalam bentuk berbagai kegiatan, dan tidak terlalu hierarkis akan merangsang dan mendorong perkembangan kemandirian anak.

Menurut Laird (dalam Mudjiman, 2007 :14), ciri-ciri kemandirian belajar dapat dikategorikan sebagai berikut:

a. Kegiatan belajarnya bersifat mengarahkan diri sendiri tidak dependen.

b. Pertanyaan-pertanyaan yang timbul dalam proses pembelajaran dijawab sendiri atas dasar pengalaman bukan mengharapkan jawaban dari guru atau orang lain.

c. Tidak maudidekte guru.

d. Umumnya tidak sabar untuk segera memanfaatkan hasil belajar.

e. Lebih senang dengan problemcentered learning dari pada contentcenteredlearning.

f. Lebihsenangdengan partisipasi aktifdaripada pasif mendengarkan ceramah guru.

g. Selalu memanfaatkan pengalaman yangtelah dimiliki (konstruktivistik).

h. Lebih menyukai collaborative learning.

i. Perencanaan dan evaluasi belajar lebih baik dilakukan dalam batas tertentu antara siswa dan guru.

j. Belajar harus dengan berbuat tidak cukuphanya mendengarkan dan menyerap.

\section{Prestasi Belajar Siswa}

Muhibbin Syah (2008), mendefinisikan prestasi sebagai tingkat keberhasilan siswa dalam mencapai tujuan yang ditetapkan dalam sebuah program. Sumadi Suryabrata (2006:297) merumuskan prestasi sebagai nilai yang merupakan bentuk perumusan akhir yang diberikan oleh guru terkait dengan kemajuan prestasi belajar siswa selama waktu tertentu (Sardiman A.M, 2005:20), Cronbach memberi- 
kan definisi :"Learning is shown by a change inbehavior as a result of experience". Belajar adalah memperlihatkan perubahan dalam perilaku sebagai hasil dari pengalaman. Harold Spears memberikan batasan:" Learning is to observe, toread, to initiate, to try something themselves, to listen, to follow direction". Belajar adalah mengamati, membaca, berinisiasi, mencoba sesuatu sendiri, mendengarkan, mengikuti petunjuk/arahan. Geoch, mengatakan :"Learning is a change in performance as a result of practice". Belajar adalah perubahan dalam penampilan sebagai hasil praktek.

Dari ketiga definisi di atas dapat disimpulkan bahwa belajar itu senantiasa merupakan perubahan tingkah laku atau penampilan, melalui serangkaian kegiatan misalnya dengan membaca, mengamati, mendengarkan, meniru dan lain sebagainya.

Penelitian mengenai pengaruh metode belajar dan kemandirian terhadap prestasi belajar siswa pernah dilakukan oleh Dyahnita Adiningsih. Dalam penelitiannya Adiningsih (2012) menemukan adanya pengaruh positif yang signifikan persepsi siswa tentang metode mengajarguru terhadap prestasi belajara kuntansi. Hal tersebut ditunjukkan dengan hargar sebesar 0.639 dan r2 sebesar 0.09, yang berarti bahwa semakin tinggi (positif) persepsi siswa tentang metode mengajar guru maka akan semakin baik pula prestasi belajara kuntansi yang akan dicapai siswa.

Penelitian lain juga dilakukan oleh Lisna Handayani, Dantes dan Suastra yang mengungkap mengenai pengaruh model pembelajaran mandiri dan kemandirian belajar terhadap prestasi belajar IPA. Salah satu temuan penelitian adalah perbedaan prestasi belajar IPA yang signifikan antara siswa yang mengikuti model pembelajaran mandiri dengan siswa yang mengikuti model pembelajaran konvensional yang ditunjukkan oleh nilai F sebesar 29,54 dan p < 0,05 . Terdapat perbedaan kemandirian belajar dan prestasi belajar IPA secara simultan antara siswa yang mengikuti model pembelajaran mandiri dengan model konvensional.

\section{Hipotesis Penelitian}

Hipotesis dirumuskan berdasarkan variabel independent dan variabel dependen. Variabel independen berupa metode mengajar 
guru (X1) dan kemandirian belajar (X2), sedangkan variabel dependen berupa prestasi belajar (Y). Pada bagian ini peneliti akan menghubungkan aspek metode mengajar guru dan kemandirian belajar siswa terhadap prestasi belajar. Aspek metode mengajar guru dan kemandirian belajar diduga mempengaruhi prestasi belajar siswa. Proposisi dalam penelitian ini adalah aspek metode mengajar guru dan kemandirian belajar mempengaruhi prestasi belajar siswa. $\mathrm{H} 1$ = metode mengajar guru berpengaruh positif terhadap prestasi belajar siswa

$\mathrm{H} 2$ = kemandirian belajar berpengaruh positif terhadap prestasi belajar siswa

Berdasarkan penjelasan diatas, kerangka pemikiran penelitian ini dapat digambarkan sebagai berikut :

\section{Variabel Independen Variabel Dependen}

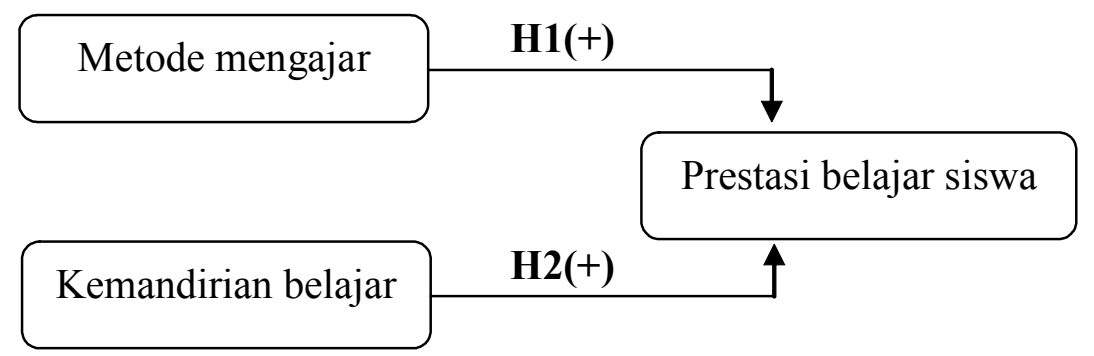

Gambar 1. Kerangka Pemikiran Penelitian

\section{Metode Penelitian}

Penelitian ini menggunakan metode kuantitatif dengan analisis regresi berganda untuk mengetahui pengaruh metode megajar guru dan kemandirian belajar terhadap prestasi belajar siswa Madrasah Aliyah di Kabupaten Kudus.

1. Pengumpulan Data dan Pemilihan Sampel

Data dalam penelitian ini adalah data primer yang diperoleh melalui metode survei dengan menggunakan kuesioner. Populasi dalam penelitian ini adalah, siswa Madrasah Aliyah di Kabupaten 
Kudus dari 17 sekolah. Sampel penelitian diambil secara purposive dengan memilih responden siswa kelas XII Madrasah Aliyah. Pemilihan responden pada kelas XII dilakukan dengan tujuan untuk mendapatkan rerata prestasi belajar siswa dari kelas $\mathrm{X}$ hingga kelas XII (semester 1 - 5). Alasan lain yang melandasi pemilihan responden adalah asumsi bahwa siswa kelas XII Madrasah Aliyah lebih mengetahui mengenai metode mengajar yang digunakan oleh guru, dikarenakan waktu belajar yang lebih lama dibanding tingkatan di bawahnya. Siswa kelas XII juga lebih bisa mendeskripsikan mengenai kemandirian belajar yang selama ini mereka terapkan pada diri mereka sendiri

2. Pengukuran Variabel

Penelitian ini menggunakan 3 variabel yang terdiri dari 1 variabel dependen (prestasi belajarsiswa) dan 2 variabel independen (metode mengajar guru dan kemandirian belajar). Semua variabel dalam penelitian ini diukur menggunakan skala likert dengan 4 skala poin, yakni 1 untuk skala terendah dan 4 untuk skala tertinggi sebagai pilihan tanggapan responden. Adapun jawaban ragu-ragu (netral) dihilangkan dengan alasan kebanyakan subyek penelitian akan cenderung memilih jawaban yang netral.

3. Pengujian Instrumen

Dalam pengujian instrumen penelitian, uji validitas dan uji reliabilitas merupakan poin penting dalam sebuah analisa data. Hal itu dilakukan untuk menguji apakah suatu alat ukur atau instrumen penelitian sudah valid dan reliabel.

4. Uji Asumsi klasik

Uji asumsi klasik merupakan uji yang digunakan sebagai syarat penggunaan metode regresi (Ghozali, 2001). Asumsi tersebut adalah asumsi normalitas, multikolinearitas, dan heterokedastisitas.

5. Pengujian Hipotesis

Dalam penelitian ini hipotesis disusun untuk menemukan apakah terdapat pengaruh metode mengajar guru dan kemandirian 
belajar terhadap prestasi belajar siswa. Oleh karena itu pengujian hipotesa dalam penelitian ini menggunakan analisis regresi berganda. Persamaan regresi untuk menguji hipotesis-hipotesis yang diajukan, dinyatakan dalam model berikut:

$\mathrm{Y}=1 . \mathrm{X} 1+2 . \mathrm{X} 2$

Keterangan:

- $\mathrm{Y}=$ Prestasi belajar siswa

- $\mathrm{X} 1$ = Metode mengajar guru

- $\mathrm{X} 2$ = Kemandirian belajar

\section{Deskripsi Data}

Jumlah keseluruhan responden yang berhasil terkumpul hingga batas akhir pengujian kuesioner adalah 187 sampel berasal dari 209 kuesioner yang ditujukan kepada siswa kelas XII dari 17 Madrasah Aliyah di Kabupaten Kudus antara lain : MA NU Mu'allimat Demaan Kota Kudus, MA Al- Hidayah Getas Serabi Gebog Kudus, MA Qudsiyyah Kauman Menara Kudus, MA Darul Ulum Conge Ngembalrejo Kudus, MA NU Ibtidaul Falah Samirejo Dawe Kudus, MA NU Hasyim Asyari 3 Kudus, MAN 1 Conge Ngembalrejo Kudus, MA NU TBS Kajeksan Kota Kudus, MA NU Wahid Hasyim Salafiyah Jekulo Kudus, MA Darul Hikam Kalirejo Undaan Kudus, MA NU Assalam Tanjung Karang Jati Kulon Kudus, MA NU Miftahul Falah Cendono Dawe Kudus, MA NU Nurussalam Besito Gebog Kudus, MA NU Hasyim Asyari 2 Karangmalang Gebog Kudus, MA NU Banat Krandon Kota Kudus, MAN 2 Prambatan Kidul Kaliwungu Kudus, MA Nahdhotul Muslimin Undaan. Tingkat pengembalian kuesioner adalah 89,5\% (187 dari 209 yang ditargetkan).

Adapun statistik deskriptif yang secara detail disajikan nilai mean, median serta deviasi standar dari masing-masing variabel ditunjukkan oleh Tabel 1. 
Tabel 1

\section{Statistik Deskriptif}

\begin{tabular}{l|c|c|c}
\hline & $\begin{array}{c}\text { Metode } \\
\text { Mengajar Guru }\end{array}$ & $\begin{array}{c}\text { Kemandirian } \\
\text { Belajar }\end{array}$ & Prestasi Belajar Siswa \\
\hline $\mathrm{N} \quad$ Valid & 187 & 187 & 187 \\
\multicolumn{1}{c|}{ Missing } & 0 & 0 & 0 \\
Mean & 60.6364 & 57.9037 & 74.6003 \\
Median & 62.0000 & 58.0000 & 72.3140 \\
Mode & $63.00 \mathrm{a}$ & 56.00 & 80.20 \\
Std. Deviation & 6.20062 & 9.83746 & 5.39867 \\
Variance & 38.448 & 96.776 & 29.146 \\
Minimum & 37.00 & 34.00 & 51.30 \\
Maximum & 72.00 & 78.00 & 90.06 \\
\hline
\end{tabular}

a. Multiple modes exist. The smallest value is shown

\section{Validitas dan Reliabilitas Instrumen}

Pengukuran validitas kuesioner menggunakan analisis korelasi bivariat model Pearson. Korelasi ini dilakukan jika sepasang variabel kontinu, memiliki korelasi. Jumlah pengamatan variabel $\mathrm{X}$ dan $\mathrm{Y}$ harus sama, atau kedua nilai variabel tersebut berpasangan. Semakin besar nilai koefisien korelasinya maka akan semakin besar pula derajat hubungan antara kedua variabel. Dari hasil uji validitas diatas dapat diketahui bahwa nilai signifikansi masing-masing variabel atau item dibawah 0,05 atau 5\%, yang artinya tingkat kepercayaan diatas $95 \%$

Sedangkan hasil uji reliabilitas instrumen menunjukkan nilai cronbach alpa sebesar 0,843. Hal ini menunjukkan bahwa instrumen bersifat reliabel, karena nilai koefisien alfanya lebih besar dari 0,60.

\section{Pengujian Asumsi Klasik}

Uji asumsi klasik yang pertama adalah normalitas, dari hasil uji normalitas menunjukkan bahwa besarnya nilai Kolmogorov-Smirnov adalah 1,311 dan signifikansinya adalah 0,064.Nilai signifikansi yang lebih dari 0,05 dapat dikatakan bahwa data tersebut berdistribusi normal. 
Table 2

\section{Hasil Uji Normalitas}

\begin{tabular}{llc}
\hline $\mathrm{N}$ & & Unstandardized Residual \\
Normal & Mean & 187 \\
Parametersa,b & Std. Deviation & .0000000 \\
Most Extreme & Absolute & 3.54591488 \\
Differences & Positive & .096 \\
& Negative & .073 \\
Kolmogorov-Smirnov Z & -.096 \\
Asymp. Sig. (2-tailed) & 1.311 \\
\hline
\end{tabular}

a. Test distribution is Normal.

b. Calculated from data.

Sedangkan terkait uji multikolinearitas yang dilihat dari nilai tolerance ofvalue dan variance inflation factor (VIF), hasil analisismenunjukkan bahwa nilai VIF semua variabel independen di bawah nilai 10 dan Tolerance of value diatas 0,10. Sehingga dapat disimpulkan dari hasil diatas maka tidak ada multikolinearitas antar variabel independen dalam model regresi.

Untuk uji heteroskedastisitas, dalam penelitian ini dilakukan uji Spearman. Dari hasil olah data yang dilakukan menunjukkan bahwa tidak ada satupun variabel yang signifikan secara statistik mempengaruhi variabel dependen nilai absolut. Hal tersebut terlihat dari probabilitas signifikansinya di atas tingkat kepercayaan 5\%. Jadi dapat disimpulkan model regresi tidak mengandung adanya Heteroskedastisitas.

\section{Pengujian Hipotesis}

Dari hasil olah data diketahui bahwa metode mengajar guru dan kemandirian belajar siswa mempengaruhi prestasi belajar sebesar $56,9 \%$, sedangkan sisanya dipengaruhi aspek yang lain. Metode mengajar guru dan kemandirian belajar siswa berpengaruh signifikan secara positif terhadap prestasi belajar dengan tingkat signifikansi kurang dari 1\%.Adapun hasil analisis statistik regresi berganda dapat dilihat pada tabel di bawah ini. 
Tabel 3

Model Summary

\begin{tabular}{|c|c|c|c|c|}
\hline Model & $\mathrm{R}$ & R Square & $\begin{array}{l}\text { Adjusted R } \\
\text { Square }\end{array}$ & $\begin{array}{l}\text { Std. Error of the } \\
\text { Estimate }\end{array}$ \\
\hline $\begin{array}{c}\text { dimensio } \\
\text { n0 }\end{array}$ & $.754^{\mathrm{a}}$ & .569 & .564 & 3.56513 \\
\hline
\end{tabular}

Tabel 4

Analysis of Variance

\begin{tabular}{llrrrrr}
\hline Model & \multicolumn{2}{c}{$\begin{array}{l}\text { Sum of } \\
\text { Squares }\end{array}$} & \multicolumn{4}{c}{ Mean } \\
& & \multicolumn{2}{l}{ Square } & \multicolumn{2}{c}{ S } \\
\hline 1 & Regression & 3082.407 & 2 & 1541.204 & 121.257 & $.000^{\mathrm{a}}$ \\
& Residual & 2338.673 & 184 & 12.710 & & \\
\hline & Total & 5421.080 & 186 & & & \\
\hline
\end{tabular}

a. Predictors: (Constant), Metode mengajar guru, Kemandirian belajar

b. Dependent Variable: Prestasi belajar siswa

\section{Tabel 5}

\section{Coefficients}

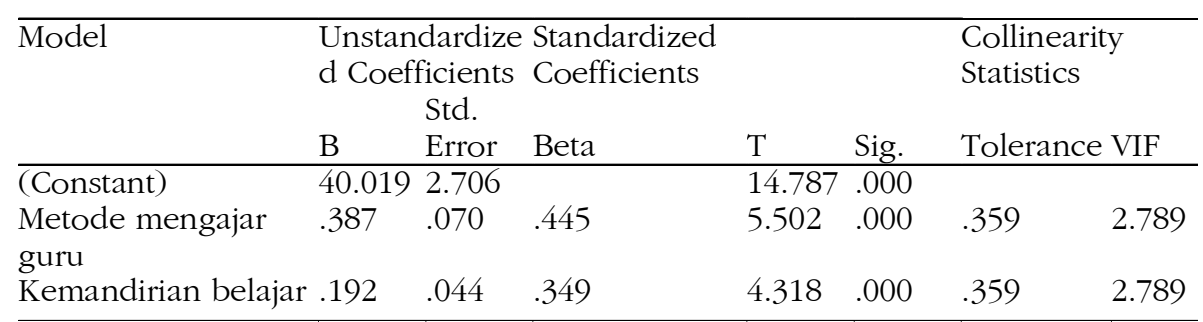

a. Dependent Variable: Prestasi Belajar

Berdasarkan hasil pengolahan data pada tabel 5, maka dapat dibentuk persamaan regresi sebagai berikut: $\mathrm{Y}=40,019+0,387 \mathrm{X} 1$ $+0,192 \times 2$

\section{Analisis}

Berdasarkan data penelitian yang dianalisis, hasil penelitian menunjukkan bahwa terdapat pengaruh positif yang signifikan metode mengajar guru dan kemandirian belajar terhadap prestasi belajar 
siswa. Dari hasil analisis dengan menggunakan regresi berganda diperoleh harga koefisien korelasi (r) sebesar0.754 dan harga koefisen determinasi (r2) sebesar 0.569. Sehingga dapat disimpulkan bahwa terdapat pengaruh positif yang signifikan metode mengajar guru dan kemandirian belajar terhadap prestasi belajarsiswa.

Perbedaan penelitian ini dengan penelitian sebelumnya adalah pada pengujian pengaruh metode mengajar guru dan kemandirian belajar terhadap prestasi siswa. Pada penelitian ini pengujian dilakukan dengan memperbanyak sampel dan memperluas daerah penelitian.Sampel penelitian berasal dari 17 Madrasah Aliyah dan daerah penelitian meliputi satu Kabupaten yaitu Kabupaten Kudus.Hasil penelitian yang didapat menguatkan teori sebelumnya bahwa metode mengajar dan kemandirian belajar berpengaruh terhadap prestasi siswa yang terlihat dari nilai R Square sebesar 0.569.

Penelitian terdahulu yang dilakukan oleh Adiningsih (2012), menemukan adanya pengaruh positif yang signifikan persepsi siswa tentang metode mengajar guru terhadap prestasi belajar akuntansi. Hal tersebut ditunjukkan dengan hargar sebesar 0.639 dan r2sebesar 0.409, yang berarti bahwa semakin tinggi (positif) persepsi siswa tentang metode mengajar guru maka akan semakin baik pula prestasi belajar yang akan dicapai siswa. Begitu pula dengan penelitian yang dilakukan oleh Lisna Handayani, Dantes dan Suastra mengungkap adanya perbedaan prestasi belajar IPA yang signifikan antara siswa yang mengikuti model pembelajaran mandiri dengan siswa yang mengikuti model pembelajaran konvensional yang ditunjukkan oleh nilai F sebesar 29,54 dan p < 0,05. Penelitian tersebut menemukan adanya perbedaan kemandirian belajar dan prestasi belajar IPA secara simultan antara siswa yang mengikuti model pembelajaran mandiri dengan model konvensional.

Metode mengajar guru dan kemandirian belajar siswa dapat berpengaruh terhadap prestasi belajar siswa dikarenakan metode mengajar dapat dikatakan sebagai alat untuk menciptakan proses mengajar dan belajar (Sudjana,2005:76). Begitu pula dengan kemandirian belajar yang ada pada siswa, dapat menjadikan pembelajaran tercapai secara maksimal.Umar Tirtarahardja dan S.L. La Sulo (2005: 50) menyatakan bahwa kemandirian dalam belajar 
adalah aktivitas belajar yang berlangsungnya lebih didorong oleh kemauan sendiri,pilihan sendiri dan tanggung jawab sendiri.

Metode mengajar dan kemandirian siswa hanya merupakan sebagian faktor yang dapat mempengaruhi prestasi. Hal ini dibuktikan dari nilai R Square hasil beberapa penelitian yang hanya mencapai antara 40\% - 60\% saja, yang berarti masih ada faktorfaktor lain yang perlu dipertimbangkan agar prestasi siswa dapat meningkat. Dalam penelitian ini metode mengajar guru dan kemandirian belajar mempengaruhi prestasi sebesar 56,9\% sedangkan 43,1\% diasumsikan berasal dari faktor lainnya. Faktor eksternal yang mempengaruhi prestasi tidak hanya terbatas pada metode mengajar guru akan tetapi juga meliputi faktor lingkungan baik alam maupun sosial, sarana prasarana, kurikulum, materi, guru/ pengajardan administrasi/manajemen. Begitu pula dengan faktor internal juga dapat dikatakan tidak terbatas pada motivasi atau kemandirian siswa. Faktor internal lainnya sepertifisiologiyang terdiri dari kondisi fisik dan kondisi panca indera, psikologi, yang terdiri dari bakat, kecerdasan, motivasi, dan kemampuan kognitif juga dapat berpengatuh terhadap prestasi belajar siswa.

Pada akhirnya prestasi dapat dimaknaisebagaipengukuran perubuhan perilaku yang bersifat afektif, kognitif maupun psikomotorik sebagai akibat pengaruh faktor internal dan eksternal dalam bentuk penilaian oleh pengajar atau guru.

\section{Kesimpulan}

Prestasi secara umum dapat dimaknai sebagai pengukuran perubuhan perilaku yang dapat bersifat afektif, kognitif maupun psikomotorik dalam bentuk penilaian oleh pengajar atau guru. Prestasi dapat dipengaruhi oleh faktor eksternal berupa metode mengajar guru dan faktor internal seperti kemandirian belajar. Metode mengajar menjadi sangat penting dikarenakan bukan hanya berfungsi mempermudah guru dalam menyampaikan materi, akan tetapi juga berfungsi untuk membangkitkan motivasi siswa dalam proses pembelajaran, dikarenakan metode mengajar dapat dikatakan sebagai alat untuk menciptakan proses mengajar dan belajar. Demikian pula dengan kemandirian belajar pada siswa, dapat menjadikan 
pembelajaran tercapai secara maksimal. Kemandirian dalam belajar adalah aktivitas belajar yang berlangsungnya lebih didorong oleh kemauan sendiri, pilihan sendiri dan tanggung jawab sendiri.

Hasil analisis menunjukkan bahwa terdapat pengaruh positif yang signifikan metode mengajar guru dan kemandirian belajar terhadap prestasi belajar siswa. Dari hasil analisis dengan menggunakan regresi berganda diperoleh harga koefisien korelasi (r) sebesar0.754 dan harga koefisen determinasi (r2) sebesar 0.569. Sehingga dapat disimpulkan bahwa terdapat pengaruh positif yang signifikan metode mengajar guru dan kemandirian belajar terhadap prestasi belajarsiswa. Metode mengajar guru dan kemandirian belajar mempengaruhi prestasi siswa sebesar 56,9\%, sedangkan 43,1\% diasumsikan dipengaruhi oleh faktor yang lain.

\section{Daftar Pustaka}

Adiningsih, Dyahnita. 2012. Pengaruh Persepsi Siswa Tentang Metode Mengajar Guru Dan Kemandirian Belajar Terhadap Prestasi Belajar Akuntansi Siswa Kelas X Program Keablian Akuntansi SMK Batik Perbaik Purworejo Tabun Ajaran 2011/ 2012. Skripsi. Yogyakarta : Universitas Negeri Yogyakarta

A.M. Sardiman. 2005. Interaksi dan Motivasi Belajar Mengajar. Jakarta : rajawali Press.

Ali, Mohammad \& Asrori, Mohammad. 2005. Psikologi Remaja. Jakarta: PT Bumi Aksara

Ghozali, I. 2001. Aplikasi Analisis Multivariate dengan Program SPSS. Semarang: Penerbit UNDIP.

H. Burhanuddin \& Wahyuni, Esa Nur. 2010. Teori Belajar dan Pembelajaran.Jogjakarta : Ar-Ruzz Media

Handayani, Ni Nyoman Lisna. Dantes, Nyoman. Suastra, I Wayan. 2013. Pengarub Model Pembelajaran Mandiri Terhadap Kemandirian Belajar dan Prestasi Belajar IPA Siawa Kelas VIII SMP N 3 Singaraja. E-Journal Program Pascasarjana Universitas Pendidikan Ganesha. Vol 3 Tahun 2013

Mudjiman, Haris. 2007. Belajar Mandiri. Surakarta: UNS PRESS Purwanto, M. Ngalim. 2007. Psikologi Pendidikan. Bandung : PT. Remaja Roesdakarya 
Sudjana, Nana. 2005. Dasar-dasar Proses Belajar Mengajar. Bandung: Sinar Baru Algasindo

Sugiyono. 2012. Metode Penelitian Pendidikan. Bandung : Alfabeta

Suryabrata, Sumadi. 2006. Psikologi pendidikan. Jakarta : PT. Raja Grafindo Perkasa

Syah, Muhibbin. 2008. Psikologi Pendidikan dengan Pendidikan Baru. Edisi Revisi. Bandung: PT Remaja Rosda Karya

Tirtarahardja, Umar \& La Sulo. 2005. Pengantar Pendidikan. Jakarta: PT Rineka Cipta

Uno, Hamzah B. 2007. Profesi Kependidikan. Jakarta: PT Bumi Aksara 